MILESA SRECKOVIC ${ }^{1}$, BRANKA KALUDJEROVIC ${ }^{2}$, SANJA JEVTIC ${ }^{3}$ ZORAN LATINOVIC ${ }^{1}$, STANKO OSTOJIC ${ }^{4}$, DJURDJE MILANOVIC ${ }^{5}$

\title{
Optical material performances, measurement by laser implementation and interpretations
}

\begin{abstract}
Optical material performances along with main response functions belong to nondestructive measurements. Lasers brought new techniques beside accuracy increase. Nonlinear techniques introduced new solutions. These could be used in industry, biomedicine, and ecology with fast material description in various phases. The paper is elaborating optical characteristics in various phases and descriptions (purity, dynamics and optical breakdowns). From the scattering point of view, water represented medium, unstable when pure comparing to organic etalons. As solvent for macromolecules and polymers it is difficult to be observed. In solutions with surface active materials, the stability of the formation is important. A few aspects of experiments and scattering theories (static and dynamic) of mono and polychromatic light including nonlinear approaches were analyzed.
\end{abstract}

Keywords: laser, scattering, optical characteristics, diffusion, surface active material.

\section{INTRODUCTION}

Optical material performances are basically linked with main material response functions. Generally dielectric $\varepsilon$, magnetic and conductive $\sigma$ performances are in metrology measured by various and different methods. The links with optical characteristics i.e. index of refraction, coefficient of reflection, could be the way for non explicit $\varepsilon, \sigma$, measurements via non- destructive methods. Beside reflective, transmittive material behavior (coefficient of extinction and reflection in Fresnel formulation), the scattering methods increase the sensitivity of measure ment) [1-3].

Lasers brought new techniques as well as accuracy increase in existing methods. The lasers are used as sources of high energy density, but as the sources with high spatial and time coherencies. High power intensity laser produced nonlinear effects (processes) in materials; they are applied as new measuring methods and represent material from nonlinear side. Tremendous optical methods are and could be used in industry, but also, they could be used in biomedicine, pharmacy, ecology, biology, physics, chemistry, in Space, etc. Depending on the state of material (phases) of the

Author's address: ${ }^{1}$ Faculty of Electrical Engineering, Belgrade, Bul. Kralja Aleksandra 73, ${ }^{2}$ Vinca Institute, University of Belgrade, P.O.Box 522, Belgrade, Serbia, ${ }^{3}$ Arhi. pro, Cerska 29, Belgrade, ${ }^{4}$ Faculty of Technology and Metallurgy University of Belgrade, Belgrade, Karnegijeva 4, ${ }^{5}$ Faculty of Computer sciences, Megatrend University, Belgrade, Serbia.

Received for Publication: 08. 08. 2013.

Accepted for Publication: 28. 11. 2013. solid state, liquid, gaseous states and developed measuring systems, the measurement could have duration in the range of $f s$ up to several minutes or more, depending on the scattering event. Techniques of photon beating, correlation spectroscopies, with techniques of nonlinear type introduced new solutions [4-7]. These could be used in mentioned applications with fast responses for material description in early phases and states. Techniques of correlation spectroscopies, Hertzian spectroscopies cover very large spectral range considering frequency shifts and linewidths. Developed light scattering methods could be based on static or dynamic devices. They existed as commercial devices for a long period of time but in various materializations and possible variations. Results interpretation (with polarization characteristics, Müller matrices and other formalisms) still poses unanswered questions. Those are nonlinear characteristics and relations to thresholds of different nature (selffocusing, optical breakdown) related to ultrashort pulses, in which area new approaches and formalisms should be used.

This paper deals with optical characteristics in various phases of material and descriptions (purity, dynamics, optical breakdowns). From the scattering point of view, water represented medium, which is unstable when pure, comparing to organic etalons. As solvent for macromolecules and polymers (weak solutions) water is hard to notice. In solutions with surface active materials (critical parameters, micelles and concentrated solutions), the stability of the formation must be taken into account. All this complex dynamic interpretation is of widespread use of interest in pharmacy, biomedicine, detergent operating mechanisms, drug absorbance and dynamics in bio fluids. 
All mechanisms are interpreted today using diffusion coefficient $D$. It took over molecular masses interpretations. Interpretations of concentrated solutions were taken by effective coefficient of diffusion Deff.

In this paper a few aspects of chosen techniques are analyzed as well as experiments from the area of static and dynamic scatterings of mono and polychromatic (white) light including nonlinear approaches, tasks of engineering nature, software, etc. (degermination, ecology, besi des scattering, characteristics laser introduced changes...) [8-25].

\section{EXPERIMENT}

In the experimental part of our paper two types of measuring devices were applied, with modification i.e. devices for static scattering with the possibility of angular distribution and devices with dynamic light scattering with photon beating processes. Those types of devices both have laser sources. They were based on $\mathrm{He} \mathrm{Ne}(5-100 \mathrm{~mW}) \mathrm{cw}$ and $A^{+}$: ion laser cw $(0.5-20 \mathrm{~W})$ systems. Detector was photomultiplier, sensible in adequate range and after amplifying block for static scattering measuring, only the total scattering intensity was presented. For the dynamic measurements, correlator (or optical spectrum analyzer) was used for signal analysis and we used both.

The experiments were performed on the measuring systems organized in the laboratories in CEA Saclay, France, directly for the needed amplification stages and incident laser intensity. We have paid attention to the effects of thermal lens in the case of phytol. The laser were of Spectra Physics products and they are implemented in most of the light scattering commercial devices, too. For static measurements, the experimental setup was the product of the laboratories design in Saclay. It gives possibility for angular distribution measurement. In those measurements we used cylindrical geometry. The most quality scattering cells (Helma) were used for cylindric as well as rectangular geometries.

Table 1a - Depolarized and polarized scattering components ( $i$ and I) and depolarization $\rho$, total and partial Rayleigh factors $R$ tot for mixture carbon tetrachloride and phytol

\begin{tabular}{|c|c|c|c|c|}
\hline $\mathbf{X}$ & $\mathbf{i}$ & $\mathbf{I}$ & $\mathbf{\rho u}$ & $\mathbf{R}$ tot \\
\hline 0 & 0.0044 & 0.578 & 0.0151 & 3.4497 \\
\hline 0.028 & 0.066 & 0.756 & 0.01854 & 3.74 \\
\hline 0.076 & 0.171 & 0.891 & 0.0926 & 6.27 \\
\hline 0.119 & 0.282 & 0.963 & 0.0662 & 7.24 \\
\hline 0.158 & 0.228 & 1.778 & 0.1320 & 11.68 \\
\hline 0.158 & 0.297 & 1.778 & 0.1043 & 12.09 \\
\hline 0.193 & 0.273 & 2.022 & 0.1164 & 13.49 \\
\hline 0.193 & 0.237 & 3.441 & 0.1508 & 13.28 \\
\hline
\end{tabular}
were performed on the optical table (which could be applied in holography, too); it means that mechanical fluctuations were damped. The analyzator and correlator were chosen in the range adequate for optical beatings and there are products of Rockland and Saicor. All products of measuring material were of $\mathrm{sp}$ purity. Phytol, who is rarely measured (as we know), via laser scattering is of Fluka product.

\section{RESULTS AND DISCUSION}

\subsection{Measurements with water}

In measuring we considered that three times distilled water with centrifugation and filtration through adequate filters directly in the special cell (rectangular or circular/cylindrical geometries) is opticaly pure. To control it we measured angular distribution from $15^{\circ}$ to $175^{\circ}$ for all polarization combinations i.e. for 'natural' light (laser without polarization) we measured horizontal and vertical components ( $\mathrm{i}$ and I) and obtained $\rho \mathrm{u}$. For polarized laser beam we measured depolarization $\rho v$ and $\rho h$. The direction of polarization of incident laser beam was rotated through adequate element. With static laser scattering, unfortunately, due to small theoretical value of depolarization i.e. 0.02 (0.04) we obtained frequently those values but the angular distribution didn't confirm that water was without dust particles. On the other hand it confirmed that water as solvent for small molecules could be the problem. Completely different were the solutions with SDS or latex spheres which were used for device calibration [4, 8-12,17].

\subsection{Solution of (conditionally) small molecules}

Starting from pure $\mathrm{CCl}_{4}$ (carbon tetrachloride) and finishing with pure phytol $\mathrm{C}_{2} \mathrm{H}_{40} \mathrm{O}$ the measurement with nonpolarized laser (components $i$ and I) and depolarization were used for obtaining total and partial Rayleigh factors ( $R_{\text {tot }}$, Rizo and Raniz) and a part of results is presented in table 1. 
Table $1 b$ - Relationship between isotrope and anisotrope Rayleigh factors $R_{i z} /$ Raniz versus molar fraction

\begin{tabular}{|l|c|c|c|c|c|c|c|c|}
\hline $\mathbf{x}$ & 0 & 0.028 & 0.076 & 0.119 & 0.158 & 0.158 & 0.193 & 0.193 \\
\hline $\mathbf{R}_{\mathbf{i z}} / \mathbf{R}_{\text {aniz }}$ & $3.34 / 0.11$ & $3.33 / 0.44$ & $4.80 / 1.41$ & $4.87 / 2.4$ & $8.76 / 1.92$ & $9.58 / 2.51$ & $10.98 / 2.51$ & $11.37 / 1.91$ \\
\hline
\end{tabular}

Considering that Rtot could be the measure for scattering power for adequate solutions, Rizo and Raniz could be the measures for the origin of the fluctuations in the sample. The Rizo is obtained due to $R_{\text {con }}$ and $R_{\text {dens }}$ i.e. as the measure of the solution ideality. $R_{\text {con }}$ is Rayleigh factor depending on the concentration fluctuations and Rdens measure of the density fluctuations in solution. That way it could be used for interpretation of mutual angle between the molecules, and it could be compared with the measurements with acoustic measurement of adequate solutions [14-16, 23].

\subsection{Link of linear and nonlinear performances}

The simple relation of hyperpolarizability of higher degree $X^{(3)}$ and nonlinear contribution of the index of refraction n2 exist.

On the other hand it is linked with anisotropy Raniz, too [6, 7] and it is the possibility to estimate the laser intensities which could be responsible for selffocussing, and other nonlinear effects [6]. It means that the formulations:

$$
n=n 0+n 2 I+n 4 t^{2}+\ldots
$$

i.e. the contributions of index of refractions of higher order can be evaluated. Oftenly, the n2 is the only important term and the other are neglected.

The obtaining of nonlinear contributions is not an easy method considering direct measuring with fast laser pulses. The differences between the measurements of hyperpolarizabilities of higher order are frequently.

\subsection{Measuring of light scattering of monomers, macromolecules and micelles}

Our measurements of coefficients of diffusion of SDS in water without salt were not repeatable. The theoretical advice is always addition of some small quantity of salt molecules. The measuring range of scattered linewidth jump to other range where critical parameters of the SDS were obtained. The measurements of SDS were actual in the time when the processes of detergent action (washing process) Europe start to analyze. For concentrated solutions, deviations of coefficient of diffusion for dilute concentration are known, but the interpretations of results are still in question. The linewidths of scattered intensities were in the range of some $\mathrm{Hz}$ for $0.175 \mathrm{M}$ (SDS in water), and $\sim 200 \mathrm{~Hz}$ (for polystyrene latex sphere $(0.199 \mathrm{~m}$ ) $[13,24]$. Another point of view is the question where Deff is the function of the concentration of salt [7].

That is the case for TTAB (M) where $\mathrm{KBr}$ is the parameter by light scattering dynamic measuring (Fig. 1).

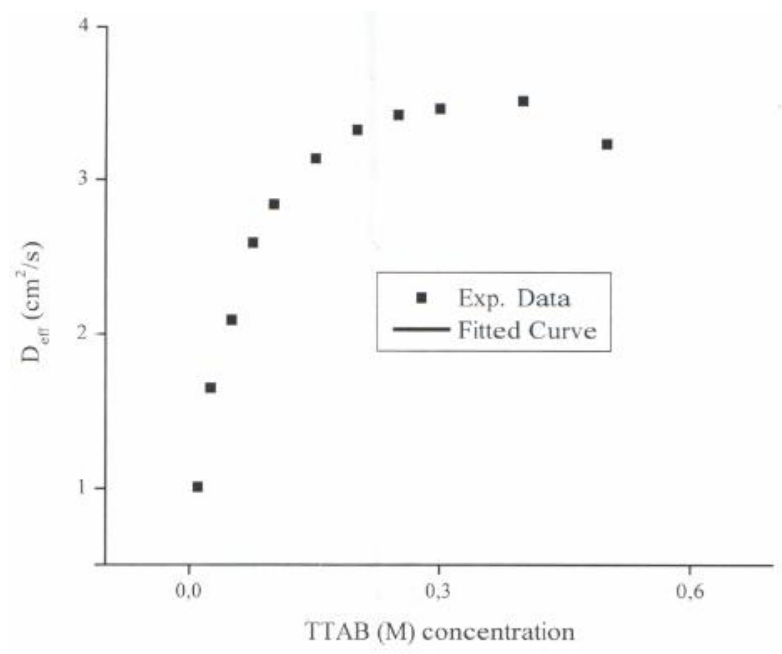

Figure 1 - Difussion coefficient Deff $\left(10^{-6} \mathrm{~cm}^{2} / \mathrm{s}\right)$ versus TTAB concentration with $\mathrm{KBr}$ addition $(0.01 \mathrm{M})$.

For comparison of possibility of different methods, we gave the classic results of obtaining molecular mass for three cases, the relationship of molecular mass and the term which present the polydispersity of the sample, Table 2; determination of macromolecules radius and Fig. 2 as the representation were the asymmetry for the angular distribution differ particle shapes (sphere, cylinder and Gaussian pellet).

Table 2 - Molecular mass $M$, diffusion coefficient $D$ and polydispersity of polystyrene in cyclohexane

\begin{tabular}{|c|c|c|c|c|c|}
\hline \multirow[b]{2}{*}{ Sample } & $M_{w} 10^{+3}$ & $\mathrm{M}_{\mathrm{z}} / \mathrm{M}_{\mathrm{w}}$ & \multirow[b]{2}{*}{$D_{z} 10^{7} \mathrm{~cm}^{2} / \mathrm{s}$} & \multirow[b]{2}{*}{$\mathrm{Mw} 10^{+5}$} & \multirow[b]{2}{*}{$\mu /^{2}$} \\
\hline & \multicolumn{2}{|c|}{$\begin{array}{l}\text { Sedimentation equilibrium, light } \\
\text { scattering }\end{array}$} & & & \\
\hline 1. Monodispersed & $4.14 .1 \pm 0.20 .2$ & 1.1 & $2.07 \pm 0.07$ & $4.1 \pm 0.02$ & $0.026 \pm 0.02$ \\
\hline $\begin{array}{l}\text { 2. Mixture } 37.5 \mathrm{M}=4.1 \quad 10^{5} \\
62.5 \% \mathrm{M}=0.51\end{array}$ & $1.86 \pm 0.1$ & 1.86 & $2.55 \pm 0.05$ & $1.98 \pm 0.05$ & $0.25 \pm 0.05$ \\
\hline 3. Polydispersed & $2.56 \pm 0.13$ & $1.24 \pm 0.05$ & $2.56 \pm 0.03$ & $2.76 \pm 0.16$ & $0.07 \pm 0.02$ \\
\hline
\end{tabular}


The term $\mu_{2} / \Gamma^{2}$ represents the degree of polydispersity with the representation of the cumulants (moments) and linewidth $\Gamma$. The subscript is linked to the molecular weight of most intensive fraction in polymer.

Table 3 - Measurement methods comparison for determination of macromolecule radius

\begin{tabular}{|l|l|l|c|}
\hline \multicolumn{1}{|c|}{ Method } & \multicolumn{1}{|c|}{ Benefits } & \multicolumn{1}{c|}{ Disadvantages } & Accurac \\
\hline By measuring D & $\begin{array}{l}\text { Quick, accurate, absolute, does } \\
\text { not introduce disturbance }\end{array}$ & No direct info about form & $1-2 \%$ \\
\hline Electronic microscopy & $\begin{array}{l}\text { Gives info about form (shape) } \\
\text { and surface structure }\end{array}$ & $\begin{array}{l}\text { Accessories must be calibrated, } \\
\text { possible form (shape) distortion } \\
\text { during forming }\end{array}$ & $5 \%$ \\
\hline $\begin{array}{l}\text { Measurement of light scat- } \\
\text { tering angle dependence }\end{array}$ & $\begin{array}{l}\text { Does not enters distor tion, } \\
\text { potentially give info about inner } \\
\text { structure }\end{array}$ & $\begin{array}{l}\text { Considerable length of the } \\
\text { experiment }\end{array}$ & $5 \%$ \\
\hline
\end{tabular}
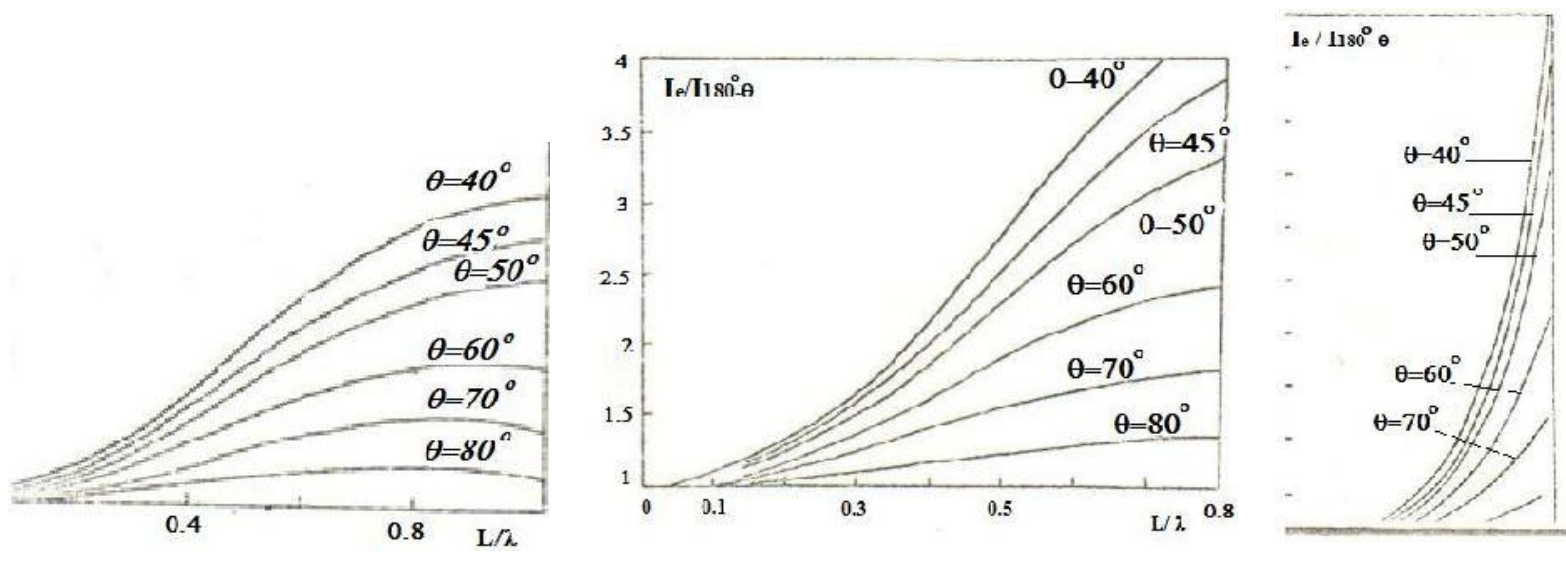

Figure 2 - Assimetries in angular functions characteristics for cylindric, sphere and Gaussian pellet geometries [17].

Linewidth of the laser which has a main role in correlation measurement depends on laser intensity and if laser is not with stabilized linewidth, it varies around lasing threshold (Figure 3 ).

It could be measured as in our results by optical correlations techniques, but also with FabryPerot, and measurements of Brillouin shifts and intensities. The analysis with linewidth and Lorentzian or Gaussian shapes, was the object of discussion and those interpretations could be the tasks for further investigation and considerations of the results of differences between the static and dynamic measurements and interpretations of results of Rayleigh and Brillouin lines [24].

The laser scattering with high intensities which provokes the breakdown processes as the basis for white lidar measurements, could be of interest from nonlinear side. From the linear one the classic scattering of white light explain the color of the powder depending on the size as the other point of view.

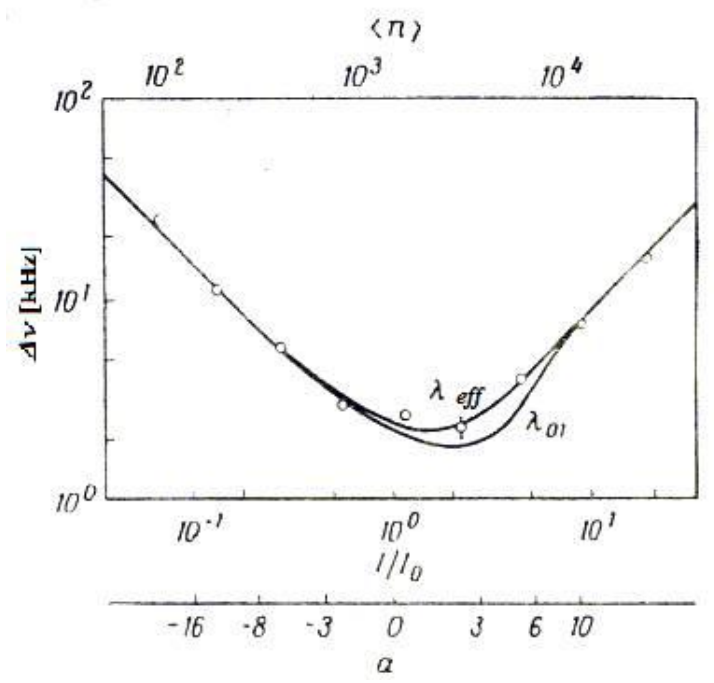

Figure 3 - Effective linewidth $\Delta v$ dependence from laser intensivity I, normalized using threshold lasing value $I_{0}$. 


\section{CONCLUSION}

In spite of the fact that the light scattering (laser scattering) is used to measure material, well known material from the dynamical point of view, was and it is the possibility to describe laser beam characteristics due to narrow spectral line of the incident laser beam. The comparison of the light scattering spectra with rotation disc and Brownian particle movement is used to obtain the laser linewidth thanks to known characteristics of the material. On the other hand, the degree of coherency of laser beam made possible photon beating experiment. Inversely, the description of laser beam coherency could be derived from light scattering experiments. There are a noticeable number of problems arriving in incoherency of various laser scattering experiments of the same meaning. They have basically various treating of laser statistics [4, 25].

An interesting point of view could be also the laser germinations of water content, due to possible irradiations of uvaser, as it is operated with other UV sources, and germicide lamps [18 ]. In this paper, the application of laser and light scattering methods are considered with the optical pure liquid systems and for micellar mileux. The measurements of polystyrene latex spheres in water solutions and natriumdodecylsulphate- water solutions were performed but with a concentration only for micellar formation. This served for analyzing and calculating their characteris tic: polydispersity and radius as well as some general characteristics and applications of lasers. The above materials were selected because we begin the calibration (polystyrene) and on the other hand, the SDS is tipical as surface active material and detergent. The same techniques are interesting point of view, more theoretical than applicable.

The same measuring devices can serve for evaluations of laser beating techniques and multimode structure of laser, but for the moment this is not analyzed; only it was found, that the measurements of principal apparatus are not disturbed if the laser has a multimode structure which is also confirmed in literature.

Laser scattering is still one of the most sensible techniques for evaluations of material characteristics, including, Rayleigh, Brillouin, Raman (complementar to IR spectroscopy) and Doppler anemometry in various modifications. Theories for various phases are different, as well as interpretations linked to molecules or lattice performances, but for plasma and powder characteristics, too.

\section{REFERENCES}

[1] F. Grum, RJ. Becherer, Optical radiation measurements. Academic Press, New York, (1979)

[2] E.D. Palik, Handbook of optical constants of solids ,Academic Press, New York (1998)

[3] D. Marcuse - New York, Principles of optical fiber measurements, Academic Press, New York (1981)

[4] Photon Beating and Spectrosocopy, Eds. H.Z.Cummins and E.R.Pike, Mir, Moskow, (1981)

[5] Dynamic Light Scattering , Ed. R. Pecora, Plenum Press, New York (1985)

[6] Nonlinear Molecular Spectroscopy, S. Kielich ed.,Mir, Moskva, (in russian)(1981)

[7] M. Srećković, S.Ostojić, B. Đokić, V. Zarubica, A. Kovačević, M. Nešić, ( 2010) Scattering, reflection, transmission in theory and practice, the estimation of nonlinear and ultrafast phenomena, Atti de la fondazione Ronchi, vol. LXV, No.4, pp.543555

[8] S. Ostojić, Ph.D Thesis, Faculty of Electrical Engineering, Belgrade, (2000).

[9] M.Sreckovic, S.Ostojic, J. Mirčevski, Dynamical light scattering ,micellar milieu and modern numerical approaches, ROMOOPTO, VIIP3 Sept. 9-12 , Bucharest ,(1997).

[10] M.F. Vuks, Light scattering in gases,liquids and solutions, Leningrad, (1978)

[11] M. Srećković, Ph.D Thesis, Faculty of Electrical Engineering, Belgrade (1979)

[12] M.Srećković, M.Drifford, J.P. Dalbiez, P. Osmokrović, (1986) Coefficients of diffusion, polydispersity and micellar performances studied by laser scattering and correlations methods, Zbornik radova XII jug. Simp. o merenjima i mernoj opremi, Belgrade, pp.507-514.(in Serb ).

[13] Z. Fidanovski, M. Srećković, S. Ostojić, J. Ilić, M. Merkle (2012) The interpretation of the inten sity of components of laser scattering by interaction with matter, Phys. Scr., T149, 1402-4896.

[14] M. Srećković, S. Blanchard, A.N.Titschenko, J.P. Leicknam, (1986) Rapports de Rayleigh, isotropes and anysotropes, facteurs de diffusion moleculaire anisotrope $\mathrm{F}$ et anisotropie optique moleculaire du phytol et de quelque solvants organique mesures à $632,8 \mathrm{~nm}$ avec un laser He-Ne, Port. Phys. 17(3-4), 181-203

[15] Z. Fidanovski, M. Srećković, (1996) Hertzian Spectroscopy of Phytol and its Solutions, Journ. of Serb. Chemic.Soc. 61, 777-783

[16] M.Srećković, R. Capitini, Z. Fidanovski, M.Drifford, S. Ostojić, J.P.Dalbiez, A. M. Titsche nko, S. Blanchard. J.P. Leicknam, Phytol as Material Viewed as Laser Dynamical and Static Sca ttering Techniques, Lasers 98 ,Tuscon 5-10.12, 1998, Proc.of Lasers 98, Eds. W. Corcoran and T.Goldman ,SoQuE,Mc Lain, pp. 539-545 (1999).

[17] S. Guinaund, Application de la methode de diffusion de la lumière à l' tude des macromolecules en solutions, Private corespondence. 
[18] Đ. R. Milanović, V.Sajfert, S. Obradović, Lj. Vujotić, B. Rosić, S. Milanović, (2011) Modified divergence theorem for UV reactor analysis and optimization, Hem. Ind. 65(4), 343-354

[19] Ž. Tomić, Ms Thesis, Belgrade, Faculty of Electrical Engineering, Belgrade (1995).

[20] M.Srećković. Ž.Tomić, S.Ostojić , J. Ilić , N. Bundaleski, R. Sekulić, V. Mlinar, (2007) Application of Laser Beam Diffraction and Scattering Methods in the Measurement of Shape and Determination of Material Parameters, Las. in Eng., 17(3-4), 179-196

[21] M. Srećković, Z. Latinović, A. Janićijević, A. Bugarinović, M. Janićijević, Z. Fidanovski, S. Polić Radovanović, S. Jevtić, (2012) Defining of critical mate- rial parameters by laser applications, Savremeni materijali, Banja Luka

[22] J.llić ,M.Srećković, (2003) Laser Light Scattering in Spray System Control, Mat. Sci. Forum, Trans. Techn. Publ. 413, 191-197

[23] M.Srećković, (1985) Brillouin spectra of liquid mixtures of phytol in carbontetrachloride and toluene,Opt. Communications, 51(2), 100-104

[24] M.Srećković, The coefficient of diffusion of small molecules mixtures, micellar milieux and their explanations on the basis of laser scattering measurements, Fizika, Vol .22, Sup.2, (1990).

[25] F. Arecchi, M.Skuly, G.Haken, V.Waidlich., Quantum Fluctuations of Laser Radiation, [Russian translation], Mir, Moscow (1974).

\section{IZVOD}

\section{OPTIČKE OSOBINE MATERIJALA, MERENJE PRIMENOM LASERA I INTERPRETACIJE}

Optičke osobine materijala sa vezama sa glavnim funkcijama odziva pripadaju nedestruktivnim merenjima. Laseri su doneli nove tehnike, pored povećanja preciznosti. Nelinearne tehnike $i$ nova rešenja se mogu koristiti $i$ u industriji, biomedicini i ekologiji, sa brzim deskripcijama materijala u raznim fazama. Rad je posvećen optičkim karakteristikama materijala u raznim fazama i predstavama (čistoće, dinamike, optičkih proboja). Sa gledišta rasejanja, voda je predstavljala sredinu, kao čista nestabilnu u odnosu na organske etalone. Kao rastvarač za makromolekule i polimere, ona se "manje vidi". Kod rastvora sa površinski aktivnim materijalima, važna je stabilnost formacija. Analizira se nekoliko aspekata teorija i eksperimenata (statičkog i dinamičkog) rasejanja mono i polihromatske svetlosti uz nelinearne prilaze.

Ključne reči: laser, rasejanje, optičke karakteristike, difuzija, površinski aktivan materijal.

Originalni naučni rad

Primljeno za publikovanje: 08. 08. 2013.

Prihvaćeno za publikovanje: 28. 11. 2013. 